\title{
Simulation of Thermal Phenomena in Body Tissue Caused by Surface Plasmon Resonance in Metal-Graphene Nanoparticles
}

\author{
N.A. Smirnova ${ }^{1}$, R.O. Malysh ${ }^{1}$, A.V. Korotun ${ }^{1, *}$, V.I. Reva ${ }^{1}$, I.M. Titov ${ }^{2}$ \\ 1 National University "Zaporizhzhia Polytechnic", 64, Zhukovsky St., 69063 Zaporizhzhia, Ukraine \\ 2 UAD Systems, 84, Alexandrovska St., 69002 Zaporizhzhia, Ukraine
}

(Received 16 August 2021; revised manuscript received 20 October 2021; published online 25 October 2021)

The possibility of using heating of body tissue upon excitation of surface plasmons in two-layer spherical metal-graphene nanoparticles for thermal destruction of malignant neoplasms has been analyzed. Drude and Kubo models have been used to determine the frequency dependences of the dielectric function of the metal core and the conductivity of the graphene shell, respectively, and the distributions of temperatures in tumor tissue and surrounding healthy tissue have been determined by solutions of nonhomogeneous thermal conductivity equations. Values of thermophysical parameters of tumor tissue and healthy human tissue known from the literature have been used for numerical estimates and calculations. The evolution of the frequency dependences of the polarizability and absorption cross-sections of the indicated nanoparticles with the variation of the radius and material of the metal core and the thickness of the graphene shell has been studied. It has been shown that an increase in the radius of the metal core or thickness of the graphene shell results in an increase in the maximum values of the imaginary part of the polarizability and absorption cross-section, which is associated with increased interaction with the electromagnetic wave with increasing bulk metal content in the composite nanoparticle and with high concentration of free electrons in graphene layers. The possibility of spectral shifts of the polarizability maxima and the absorption cross-section with the variation of the core material of a two-layer nanoparticle, due to the essential difference in the values of the frequencies of bulk plasmons and the contribution of the ion core to the dielectric function, has been demonstrated. It has been established that the thermal conductivity is quasi-steady in the problem of heating of body tissue upon excitation of surface plasmon resonance in a composite nanoparticle. It has been proved that this method of cancer therapy is harmless to healthy tissue surrounding the tumor due to their extremely low heat. The results of numerical modeling demonstrate the need to use a conglomerate of metal-graphene nanoparticles in order to increase the effectiveness of therapy.

Keywords: Metal-graphene nanoparticle, Polarizability, Absorption cross-section, Plasmon resonance, Thermal destruction.

DOI: $10.21272 /$ jnep.13(5).05010

PACS numbers: 73.20.Mf, 78.67.Bf

\section{INTRODUCTION}

The absorption of electromagnetic radiation by metal nanoparticles in the visible and infrared regions of the spectrum is of interest due to its potential application in medicine and biology [1]. Irradiated particles can absorb energy through various channels. One of such channels is the excitation of surface plasmons, which results in local heating. Such an effect can be used for biological visualization [2-4] or thermal destruction of malignant neoplasms [5, 6].

Photothermal therapy with the use of nanoparticles is a promising method of therapy with minimal side effects $[7,8]$. This method uses nanoparticles with high optical absorption and high efficiency of converting light into heat in the near infrared region in order to generate heat in the local area of the malignant tumor. When the local temperature of the tumor reaches $42^{\circ} \mathrm{C}$, apoptosis occurs in cancer cells due to the fact that they are more sensitive to heat than normal cells, and at higher temperatures cancer cells die as a result of rapid necrosis [9]. The degree of temperature rise and the duration of therapy are two of the most important factors in this method of cancer treatment, which largely depends on the choice of the nanoparticle $[10,11]$.

In order to achieve the effectiveness of photothermal therapy, nanoparticles must have a high absorp- tion cross-section within the biological transparency window (700-1400 $\mathrm{nm}$ ) [12]. Tissues are transparent to the incident light in these spectral windows due to low absorption and light scattering; therefore, nanoparticles with high photothermal conversion efficiency can be successful candidates even when using low-power laser sources [13]. Moreover, nanoparticles used in photothermal therapy must have hypotoxicity and high solubility in biocompatible fluids in order to achieve minimal side effects and easy access to cancerous tumors even with low blood circulation [14, 15].

Due to advances in nanotechnology, in recent years, both noble metal nanoparticles and oxide nanoparticles have been used to treat cancer [16-20]. Still, metal nanoparticles, in particular gold ones, exhibit low thermal stability under long-term laser irradiation [21]. Moreover, the lack of a suitable functionalization of the surface for gold nanoparticles causes a limitation of their use in practice. Thus, modification of the surface of nanoparticles with cetyltrimethylammonium bromide is harmful to human cells. An alternative way for the solution of the indicated problems is to use graphene as a protective layer for metal nanoparticles in biological media. It results from the fact that graphene with controlled thickness has increased strength and stability in biological media. This, in turn, leads to an increase in the thermal stability of metal nanoparticles under

\footnotetext{
*andko@zp.edu.ua
} 
long-term laser irradiation, as well as to an increase in the surface area for loading anticancer drugs and provides, for example, the possibility of simultaneous use of photothermal therapy and chemotherapy [22, 23].

Thus, the problem associated with the simulation of thermal processes in body tissue caused by plasmonic phenomena in metal nanoparticles, covered with a graphene layer, is actual in terms of biomedical application of plasmonics.

\section{SIMULATION OF THE HEATING OF BODY TISSUE BY EXCITATION OF SURFACE PLASMONS}

\subsection{Temperature Distribution in the Vicinity of Plasmonic Nanoparticles}

Let us consider a metal nanoparticle with radius $R_{\mathrm{c}}$ covered with a graphene layer with thickness $t$ ( $t=N t_{\mathrm{G}}=R-R_{\mathrm{c}}$, where $N$ is the number of graphene layers, $t_{\mathrm{G}}=0.335 \mathrm{~nm}$ is the thickness of a monoatomic graphene layer, $R$ is the total radius of the particle), which is in a medium with dielectric permittivity $\epsilon_{\mathrm{d}}$, which heats the surrounding body tissue by means of excitation of surface plasmon resonance (Fig 1).

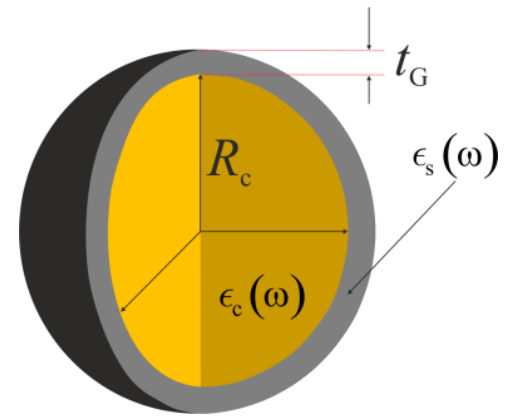

Fig. 1 - Geometry of the problem

Temperature distributions in a malignant tumor (medium 1) and in the surrounding tissue (medium 2) are determined by solutions of thermal conductivity equations in these media

$$
\begin{gathered}
\rho_{1} c_{1} \frac{\partial T_{1}}{\partial t}=\lambda_{1} \frac{1}{r^{2}} \frac{\partial}{\partial r}\left(r^{2} \frac{\partial T_{1}}{\partial r}\right)+Q_{1}, \quad 0<r<R_{t} \\
\rho_{2} c_{2} \frac{\partial T_{2}}{\partial t}=\lambda_{2} \frac{1}{r^{2}} \frac{\partial}{\partial r}\left(r^{2} \frac{\partial T_{2}}{\partial r}\right)+Q_{2}, \quad r>R_{t},
\end{gathered}
$$

where $R_{t}$ is the radius of the tumor; $\rho, c$ and $\lambda$ are, respectively, the density, specific heat capacity and thermal conductivity of the corresponding media.
Equations (1) are solved with the initial conditions

$$
T_{1}(r, 0)=T_{2}(r, 0)=T_{0},
$$

where $T_{0}$ is the initial temperature of the body tissue; the boundary conditions of boundedness of the temperature at $r \rightarrow 0$ and $r \rightarrow \infty$

$$
\left.T_{1}\right|_{r \rightarrow 0}<\infty,\left.T_{2}\right|_{r \rightarrow \infty}<\infty
$$

and equalities of temperatures and heat fluxes on the interface between healthy tissue and the tumor

$$
\left.T_{1}\right|_{r=R_{t}}=\left.T_{2}\right|_{r=R_{t}},\left.\quad \lambda_{1} \frac{\partial T_{1}}{\partial r}\right|_{r=R_{t}}=\left.\lambda_{2} \frac{\partial T_{2}}{\partial r}\right|_{r=R_{t}} .
$$

The density of heat sources in the first and second media

$$
Q_{1}=Q_{1 m}+Q_{1 b}+Q, Q_{2}=Q_{2 m}+Q_{2 b}
$$

where

$$
\begin{gathered}
Q_{1 b}=w_{1 b} C_{b}\left(T_{0}-T_{1}\right), Q_{1 m}=Q_{1 m_{0}}\left(1+0,1\left(T_{1}-T_{0}\right)\right), \\
Q_{2 b}=w_{2 b} C_{b}\left(T_{0}-T_{2}\right), Q_{2 m}=Q_{2 m_{0}}\left(1+0,1\left(T_{2}-T_{0}\right)\right), \\
Q=-\frac{d I}{d r}=k_{a} I_{0} \mathrm{e}^{-k_{a} r},
\end{gathered}
$$

$Q$ is the density of the heat flux from the laser; $k_{a}$ is the absorption coefficient, $k_{a}=C_{@}^{\mathrm{abs}} N_{T}+k_{t} ; N_{T}$ is the concentration of particles inside the tumor; $Q_{1 b}, Q_{2 b}$ are the densities of the heat flux, resulting from blood circulation in the tumor (environment); $w_{1 b}, w_{2 b}$ are the perfusion rates in the tumor and in the medium, which surrounds it, respectively; $C b$ is the heat capacity of blood; $Q_{1 m}, Q_{2 m}$ are the densities of the heat flux resulting from the metabolism; $I_{0}$ is the maximum intensity of the energy emitted by the laser,

$$
C_{@}^{\mathrm{abs}}=\frac{\omega}{c} \sqrt{\epsilon_{\mathrm{d}}} \operatorname{Im} \alpha_{@}
$$

is the absorption cross-section, $\alpha_{@}$ is the polarizability of the metal-graphene nanoparticle.

Passing to temperature differences and performing Laplace transforms, from equations (1) we obtain the following ordinary differential equations for Laplace images of temperature differences

$$
\begin{array}{cc}
\frac{1}{r^{2}} \frac{d}{d r}\left(r^{2} \frac{d \overline{\tilde{T}}_{1}}{d r}\right)-\frac{1}{\lambda_{1}}\left(\rho_{1} c_{1} p+w_{1 b} c_{b}-0,1 Q_{1 m_{0}}\right) \overline{\tilde{T}}_{1}=\frac{1}{\lambda_{1} p} Q_{1 m_{0}}+\frac{k_{a} I_{0}}{\lambda_{1} p} \mathrm{e}^{-k_{a} r}, & 0<r<R ; \\
\frac{1}{r^{2}} \frac{d}{d r}\left(r^{2} \frac{d \overline{\tilde{T}}_{2}}{d r}\right)-\frac{1}{\lambda_{2}}\left(\rho_{2} c_{2} p+w_{2 b} c_{b}-0,1 Q_{2 m_{0}}\right) \overline{\tilde{T}}_{2}=\frac{Q_{2 m_{0}}}{\lambda_{2} p}, & r>R,
\end{array}
$$

where $p$ is the parameter of the Laplace transform.

Solutions of equations (10), which satisfy the condi- tions of finiteness of functions $\overline{\tilde{T}}_{1}(r, p)$ and $\overline{\tilde{T}}_{2}(r, p)$ at $r \rightarrow 0$ and $r \rightarrow \infty$ 
have the form

$$
\left.\overline{\tilde{T}}_{1}\right|_{r \rightarrow 0}<\infty,\left.\overline{\tilde{T}}_{2}\right|_{r \rightarrow \infty}<\infty,
$$

$$
\overline{\tilde{T}}_{2}(r, p)=\frac{C(p)}{\sqrt{r}} K_{1 / 2}\left(\sqrt{b_{2}(p)} r\right)-\frac{Q_{2 m_{0}}}{\lambda_{2} p b_{2}(p)}
$$

$$
\begin{gathered}
\overline{\tilde{T}}_{1}(r, p)=\frac{B(p)}{\sqrt{r}} I_{1 / 2}\left(\sqrt{b_{1}(p)} r\right)+\frac{f(r, p)}{p}-\frac{Q_{1 m_{0}}}{\lambda_{1} p b_{1}(p)}, \quad(11) \\
f(r, p)=r^{-1 / 2}\left\{K_{1 / 2}\left(\sqrt{b_{2}(p)} r\right) \int \frac{g(r) I_{1 / 2}\left(\sqrt{b_{1}(p)} r\right)}{\mathrm{Z}(r, p)} d r-I_{1 / 2}\left(\sqrt{b_{1}(p)} r\right) \int \frac{g(r) K_{1 / 2}\left(\sqrt{b_{2}(p)} r\right) d r}{\mathrm{Z}(r, p)}\right\}, \\
\mathrm{Z}(r, p)=I_{1 / 2}\left(\sqrt{b_{1}(p)} r\right)\left[r^{-1 / 2} K_{1 / 2}\left(\sqrt{b_{2}(p)} r\right)\right]^{\prime}-K_{1 / 2}\left(\sqrt{b_{2}(p)} r\right)\left[r^{-1 / 2} I_{1 / 2}\left(\sqrt{b_{1}(p)} r\right)\right]^{\prime},
\end{gathered}
$$$$
g(r)=\frac{k_{a} I_{0}}{\lambda_{1}} \mathrm{e}^{-k_{a} r}
$$$$
b_{1}(p)=\frac{\rho_{1} c_{1} p+w_{1 b} c_{b}-0,1 Q_{1 m_{0}}}{\lambda_{1}},
$$$$
b_{2}(p)=\frac{\rho_{2} c_{2} p+w_{2 b} c_{b}-0,1 Q_{2 m_{0}}}{\lambda_{2}}
$$

where $I_{1 / 2}(x)$ and $K_{1 / 2}(x)$ are the modified spherical

Bessel functions, and the coefficients $B(p)$ and $C(p)$ are determined from the boundary conditions

$$
\overline{\tilde{T}}_{1}(R, p)=\overline{\tilde{T}}_{2}(R, p),\left.\lambda_{1} \frac{d \overline{\tilde{T}}_{1}}{d r}\right|_{r=R_{t}}=\left.\lambda_{2} \frac{d \overline{\tilde{T}}_{2}}{d r}\right|_{r=R_{t}} .
$$

As long as $\sqrt{b_{1}(p)} r<<1$ and $\sqrt{b_{2}(p) r}<<1$, we have the following asymptotics:

$$
\begin{aligned}
& I_{1 / 2}\left(\sqrt{b_{1}(p) r}\right) \cong \sqrt{\frac{2}{\pi} \sqrt{b_{1}(p) r}} ; \\
& K_{1 / 2}\left(\sqrt{b_{2}(p) r}\right) \cong \sqrt{\frac{\pi}{2 \sqrt{b_{2}(p) r}}} .
\end{aligned}
$$

Due to this fact, the asymptotic expressions for the coefficients $B(p)$ and $C(p)$ have the form

$$
\begin{aligned}
B(p) & \cong \sqrt{\frac{\pi}{2 \sqrt{b_{1}(p)}}}\left\{\frac{Q_{1 m 0}}{\lambda_{1} p b_{1}(p)}-\frac{Q_{2 m 0}}{\lambda_{2} p b_{2}(p)}+\right. \\
& \left.+\frac{I_{0}}{k_{a} \lambda_{1}}\left(1+k_{a} R_{t}\right) \mathrm{e}^{-k_{a} R_{t}}\right\} ; \quad C(p) \cong 0 .
\end{aligned}
$$

Hence, the Laplace transforms of temperatures have the form

$$
\begin{gathered}
\overline{\tilde{T}}_{1}(r, p) \cong-\frac{Q_{2 m 0}}{p\left(\rho_{2} c_{2} p+w_{2 b} c_{b}-0,1 Q_{2 m 0}\right)}+\frac{I_{0}}{k_{a} \lambda_{1} p}\left\{\left(1+k_{a} r\right) \mathrm{e}^{-k_{a} r}-\left(1+k_{a} R_{t}\right) \mathrm{e}^{-k_{a} R_{t}}\right\}, \\
\overline{\tilde{T}}_{2}(r, p) \cong \frac{Q_{2 m 0}}{p\left(\rho_{2} c_{2} p+w_{2 b} c_{b}-0,1 Q_{2 m 0}\right)} .
\end{gathered}
$$

Returning from images (15) and (16) to the origi- nals, we finally obtain

$$
\begin{gathered}
T_{1}(r, t)=T_{0}+\frac{I_{0}}{k_{a} \lambda_{1}}\left\{\left(1+k_{a} r\right) \mathrm{e}^{-k_{a} r}-\left(1+k_{a} R_{t}\right) \mathrm{e}^{-k_{a} R_{t}}\right\}+\frac{Q_{2 m 0}}{w_{2 b} c_{b}-0,1 Q_{2 m 0}}\left(1-\mathrm{e}^{-\frac{w_{2 b} c_{b}-0,1 Q_{2 m 0}}{\rho_{2} c_{2}} t}\right), \\
T_{2}(r, t)=T_{0}+\frac{Q_{2 m 0}}{w_{2 b} c_{b}-0,1 Q_{2 m 0}}\left(1-\mathrm{e}^{-\frac{w_{2 b} c_{b}-0,1 Q_{2 m 0}}{\rho_{2} c_{2}} t}\right) .
\end{gathered}
$$

Thereafter, relations (17) and (18) will be used to study the temperature distributions in tumor tissues and healthy tissues which surround it.

\subsection{Optical Characteristics of Metal-graphene Nanoparticles}

As noted above, the density of the heat source $Q$ is directly proportional to the absorption cross-section $C_{@}^{\text {abs }}$. Thus, let us define it for a metal-graphene nanoparticle by calculating the imaginary part of its polarizability [24]

$$
\alpha_{@}=R^{3} \frac{\left(\epsilon_{\mathrm{s}}-\epsilon_{\mathrm{d}}\right)\left(2 \epsilon_{\mathrm{s}}+\epsilon_{\mathrm{c}}\right)-\left(2 \epsilon_{\mathrm{s}}+\epsilon_{\mathrm{d}}\right)\left(\epsilon_{\mathrm{s}}-\epsilon_{\mathrm{c}}\right) \beta_{\mathrm{c}}}{\left(\epsilon_{\mathrm{s}}+2 \epsilon_{\mathrm{d}}\right)\left(\epsilon_{\mathrm{c}}+2 \epsilon_{\mathrm{d}}\right)-2\left(\epsilon_{\mathrm{s}}-\epsilon_{\mathrm{d}}\right)\left(\epsilon_{\mathrm{s}}-\epsilon_{\mathrm{c}}\right) \beta_{\mathrm{c}}},
$$

where $\beta_{\mathrm{c}}$ is the bulk metal content in the nanoparticle, and the dielectric function of the metal core in the Drude model has the form

$$
\epsilon_{\mathrm{c}}(\omega)=\epsilon^{\infty}-\frac{\omega_{p}^{2}}{\omega^{2}+\gamma_{\mathrm{eff}}^{2}}+\mathrm{i} \frac{\omega_{p}^{2} \gamma_{\mathrm{eff}}}{\omega\left(\omega^{2}+\gamma_{\text {eff }}^{2}\right)} .
$$


Here $\epsilon^{\infty}$ is the contribution of the ion core to the dielectric function of the metal; $\omega_{p}=\sqrt{e^{2} n_{e} / \epsilon_{0} m^{*}}$ is the frequency of bulk plasmons, $e, n_{e}$ and $m^{*}$ are, respectively, the charge, concentration and effective mass of an electron $\left(n_{e}^{-1}=4 \pi r_{s}^{3} / 3, r_{s}\right.$ is the mean distance between conduction electrons), and the effective relaxation rate

$$
\gamma_{\text {eff }}=\gamma_{\text {bulk }}+\gamma_{\mathrm{s}}+\gamma_{\text {rad }},
$$

where $\gamma_{\text {bulk }}$ is the bulk relaxation rate, $\gamma_{\mathrm{s}}$ is the rate of relaxation associated with scattering on the surface [25]

$$
\gamma_{\mathrm{s}}=/\left(\omega, R_{\mathrm{c}}\right) \frac{v_{\mathrm{F}}}{R_{\mathrm{c}}}
$$

In $(22), v_{\mathrm{F}}=\sqrt{2 \varepsilon_{\mathrm{F}} / m^{*}}$ is the Fermi velocity, $\varepsilon_{\mathrm{F}}$ is the Fermi energy of electrons in the metal; $/\left(\omega, R_{\mathrm{c}}\right)$ is the effective parameter which describes the degree of loss of coherence during electron scattering on the surface, which depends on the radius of the nanoparticle and on the frequency in the general case

$$
\mathscr{C}\left(\omega, R_{\mathrm{c}}\right)=\frac{1}{4}\left(\frac{\omega_{\mathrm{p}}}{\omega}\right)^{2}\left[1-\frac{2 v_{s}}{\omega} \sin \frac{\omega}{v_{s}}+\frac{2 v_{s}^{2}}{\omega^{2}}\left(1-\cos \frac{\omega}{v_{s}}\right)\right],
$$

where $v_{s}=v_{\mathrm{F}} / 2 R_{\mathrm{c}}$.

The last term in (21) is associated with the fact that during the decay of surface plasmons, in addition to surface scattering, an important role is played by the attenuation of radiation, which becomes especially noticeable with an increase in the radius of the metal core [26]

$$
\gamma_{\mathrm{rad}}=\frac{1}{24 \pi} \frac{V_{0}}{\sqrt{\epsilon_{\mathrm{d}}\left(2 \epsilon_{\mathrm{d}}+\epsilon^{\infty}\right)}}\left(\frac{\omega_{p}}{c}\right)^{3}\left(\frac{\omega_{p}}{\omega}\right)^{2} \frac{v_{\mathrm{F}}}{R_{\mathrm{c}}},
$$

where $V_{0}=4 \pi R_{\mathrm{c}}^{3} / 3$ is the volume of the metal core.

One can write down the following for the dielectric function of the graphene shell [27]:

$$
\epsilon_{\mathrm{s}}(\omega)=\epsilon_{\mathrm{G}}(\omega)=\frac{1}{3} \epsilon_{\mathrm{G}}^{\perp}+\frac{2}{3} \epsilon_{\mathrm{G}}^{\|}
$$

where $\epsilon_{\mathrm{G}}^{\perp}=2.5$,

$$
\epsilon_{\mathrm{G}}^{\|}(\omega)=\epsilon_{\mathrm{G}}^{\perp}+\mathrm{i} \frac{\sigma_{\mathrm{G}}(\omega)}{\epsilon_{0} \omega t_{\mathrm{G}}},
$$

$\sigma_{\mathrm{G}}(\omega)$ is the graphene conductivity, which is defined as the sum of the contributions of interband and intraband transitions according to the Kubo theory [27]

$$
\sigma_{\mathrm{G}}(\omega)=\sigma_{\text {intra }}(\omega)+\sigma_{\text {inter }}(\omega)
$$

$$
\begin{gathered}
\sigma_{\text {intra }}(\omega)=\frac{\mathrm{i} e^{2} k_{\mathrm{B}} T}{\pi \hbar^{2}\left(\omega+\mathrm{i} \gamma_{\mathrm{G}}\right)}\left\{\frac{\mu_{\mathrm{c}}}{k_{\mathrm{B}} T}+2 \ln \left(\mathrm{e}^{-\frac{\mu_{\mathrm{c}}}{k_{\mathrm{B}} T}}+1\right)\right\}, \\
\sigma_{\text {inter }}(\omega)=\frac{\mathrm{i} e^{2}}{4 \pi \hbar^{2}} \ln \frac{2\left|\mu_{c}\right|-\hbar\left(\omega+\mathrm{i} \gamma_{\mathrm{G}}\right)}{2\left|\mu_{c}\right|+\hbar\left(\omega+\mathrm{i} \gamma_{\mathrm{G}}\right)} .
\end{gathered}
$$

Here $\mu_{c}$ and $\gamma_{G}$ are, respectively, the chemical potential (Fermi energy) and the relaxation rate of electrons in graphene.

\section{CALCULATION RESULTS AND DISCUSSION}

The calculations were performed for metalgraphene nanoparticles with cores of different metals located in tumor tissue. The parameters of metals and body tissue are given in Table 1, Table 2 and Table 3.

Fig. 2 shows the frequency dependences of the real and imaginary parts, as well as the modulus of the polarizability of metal-graphene nanoparticles with different radii of the metal core. It should be pointed out that the increase in the radius of the core results in an increase in the peak values $\operatorname{Re} \alpha_{@}$ and $\operatorname{Im} \alpha_{@}$. In addition, the "red" shift of the maximum is insignificant. An increase in the maximum value of the imaginary part, which corresponds to surface plasmon resonance, can be explained by an increase in the content of the metal fraction in the nanoparticle, and correspondingly, by amplification of the response to external electromagnetic effects.

Table 1 - Parameters of metals ( $a_{0}$ is the Bohr radius)

\begin{tabular}{|c||c|c|c|c|c|}
\hline \multirow{2}{*}{ Value } & \multicolumn{5}{|c|}{ Metals } \\
\cline { 2 - 6 } & $\mathrm{Al}$ & $\mathrm{Cu}$ & $\mathrm{Au}$ & $\mathrm{Ag}$ & $\mathrm{Pt}$ \\
\hline \hline$r_{s} / a_{0}$ & 2.07 & 2.11 & 3.01 & 3.02 & 3.27 \\
\hline \multirow{2}{*}{$m^{*} / m_{e}$} & $\begin{array}{c}1.06 \\
1.48\end{array}$ & 1.49 & 0.99 & 0.96 & 0.54 \\
& 1.60 & & & & \\
\hline$\gamma_{\text {bulk }}, 10^{14} \mathrm{~s}^{-1}$ & 1.25 & 0.37 & 0.35 & 0.25 & 1.05 \\
\hline
\end{tabular}

Table 2 - Parameters of body tissues [27]

\begin{tabular}{|c||c|c|}
\hline \multirow{2}{*}{ Parameter } & \multicolumn{2}{c|}{ Value } \\
\cline { 2 - 3 } & $\begin{array}{c}\text { Medium 1 } \\
\text { (tumor) }\end{array}$ & $\begin{array}{c}\text { Medium } 2 \\
\text { (healthy } \\
\text { tissue) }\end{array}$ \\
\hline$\rho, \frac{\mathrm{kg}}{\mathrm{m}^{3}}$ & 1080 & 1050 \\
\hline$\lambda, \frac{\mathrm{W}}{\mathrm{m} \cdot \mathrm{K}}$ & 0.54 & 0.58 \\
\hline$w_{b}, \frac{\mathrm{kg}}{\mathrm{m}^{3} \cdot \mathrm{s}}$ & 0.689 & 0.540 \\
\hline$Q_{m 0}, \frac{\mathrm{W}}{\mathrm{m}^{3}}$ & 0.52 & 0.52 \\
\hline$c, \frac{\mathrm{J}}{\mathrm{kg} \cdot \mathrm{K}}$ & 3700 & 3700 \\
\hline
\end{tabular}


Table 3 - Parameters of graphene and tumor tissue [27]

\begin{tabular}{|c|c||c||}
\hline \multicolumn{2}{|c||}{ Graphene } & Tumor tissue \\
\hline$\mu_{\mathrm{c}}, \mathrm{eV}$ & $\gamma_{\mathrm{G}}, 10^{12} \mathrm{~s}^{-1}$ & $\epsilon_{\mathrm{d}}$ \\
\hline 0.1 & 6.67 & 1.2 \\
\hline
\end{tabular}
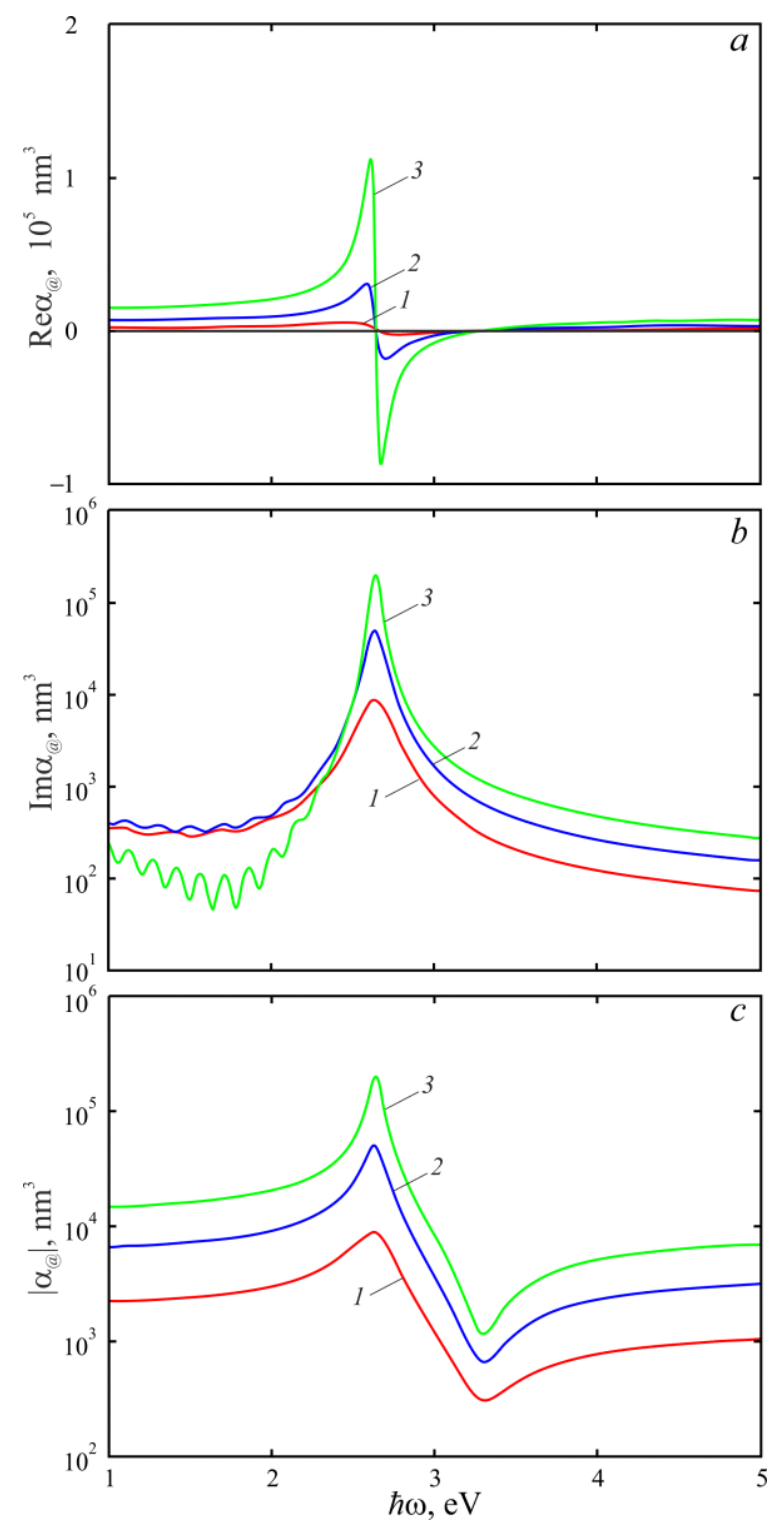

Fig. 2 Frequency dependences of the real (a) and imaginary (b) parts, and the modulus (c) of the polarizability of metalgraphene nanoparticles with different radius of the core: $1-R_{c}=10 \mathrm{~nm}, N=10 ; 2-R_{c}=15 \mathrm{~nm}, N=10 ; 3-R_{c}=20 \mathrm{~nm}$, $N=10$

Fig. 3 shows the similar dependences for nanoparticles with different thicknesses of the graphene shell. The calculations show the increase in extreme values $\operatorname{Re} \alpha_{@}, \operatorname{Im} \alpha_{@}$ and $\left|\alpha_{@}\right|$, which indicates the manifestation of the metallic properties of nanoscale graphene layers.

Fig. 4 shows the frequency dependences of the absorption cross-sections of metal-graphene nanoparticles with different values of the radius of the metal core, the thickness of the graphene shell, and the cores of different metals. The results of the calculations show
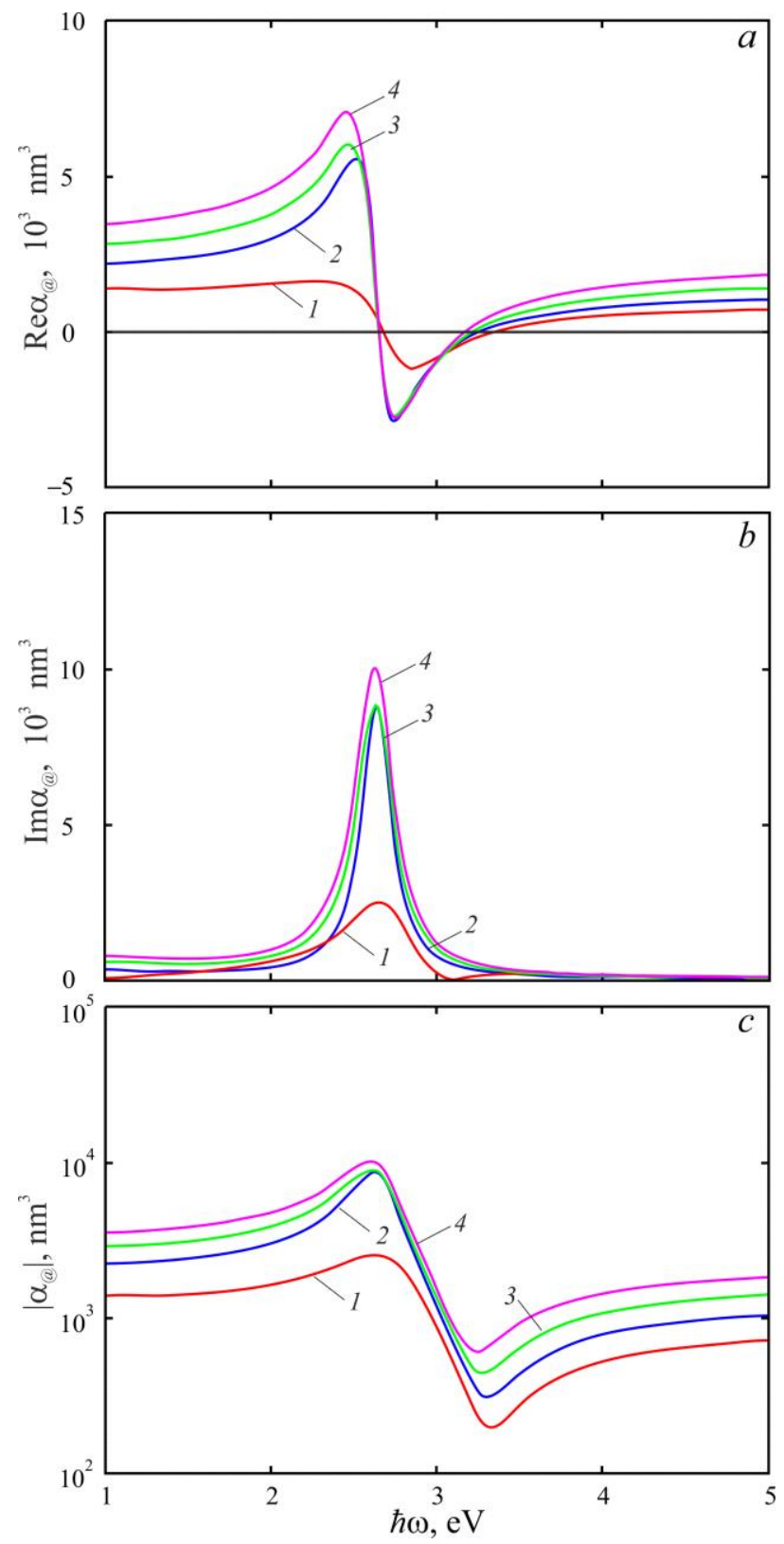

Fig. 3 Frequency dependences of the real (a) and imaginary (b) parts, and the modulus (c) of the polarizability of metalgraphene nanoparticles with different thickness of graphene layers: $\quad 1-R_{c}=10 \mathrm{~nm}, N=1 ; \quad 2-R_{c}=10 \mathrm{~nm}, N=10$; $3-R_{c}=10 \mathrm{~nm}, N=20 ; 4-R_{c}=10 \mathrm{~nm}, N=30$

that the spectral location of the maxima of the absorption cross-sections corresponds to the surface plasmon resonance frequency and does not change either with the variation of the core radius, or with the variation of the thickness of the graphene shell (Fig. 4a, b). The "blue" shift of the maxima of absorption cross-sections for particles with cores $\mathrm{Au} \rightarrow \mathrm{Cu} \rightarrow \mathrm{Ag} \rightarrow \mathrm{Pt} \rightarrow \mathrm{Al}$ takes place in the case of nanoparticles with cores of different metals. This fact can be explained by the increase in the frequency of bulk plasmons in the indicated sequence of metals.

The maximum value of the absorption cross-sections $C_{@}^{\mathrm{abs}}$ is used to estimate $k_{a}$ and calculate the temperature distributions in tissues of malignant neoplasms. 
It should be pointed out that for the considered body tissue

$$
\frac{Q_{2 m 0}}{w_{2 b} c_{b}-0,1 Q_{2 m 0}} \sim 10^{-4} \mathrm{~K},
$$

hence, the thermal conductivity is considered to be quasi-steady. Moreover, the estimation shows that the healthy tissue, which surrounds the tumor, is heated insignificantly (by ten thousandths of a degree). This means that the given method of cancer therapy is harmless to the healthy tissue surrounding the tumor.

Fig. 5 shows the graphs of radial temperature distributions in tumor tissues. The results of the calculations show that the variation of the sizes of the nanoparticle core affects the amount of heating and the size of the heating domain much more strongly than the variation of the graphene shell thickness.
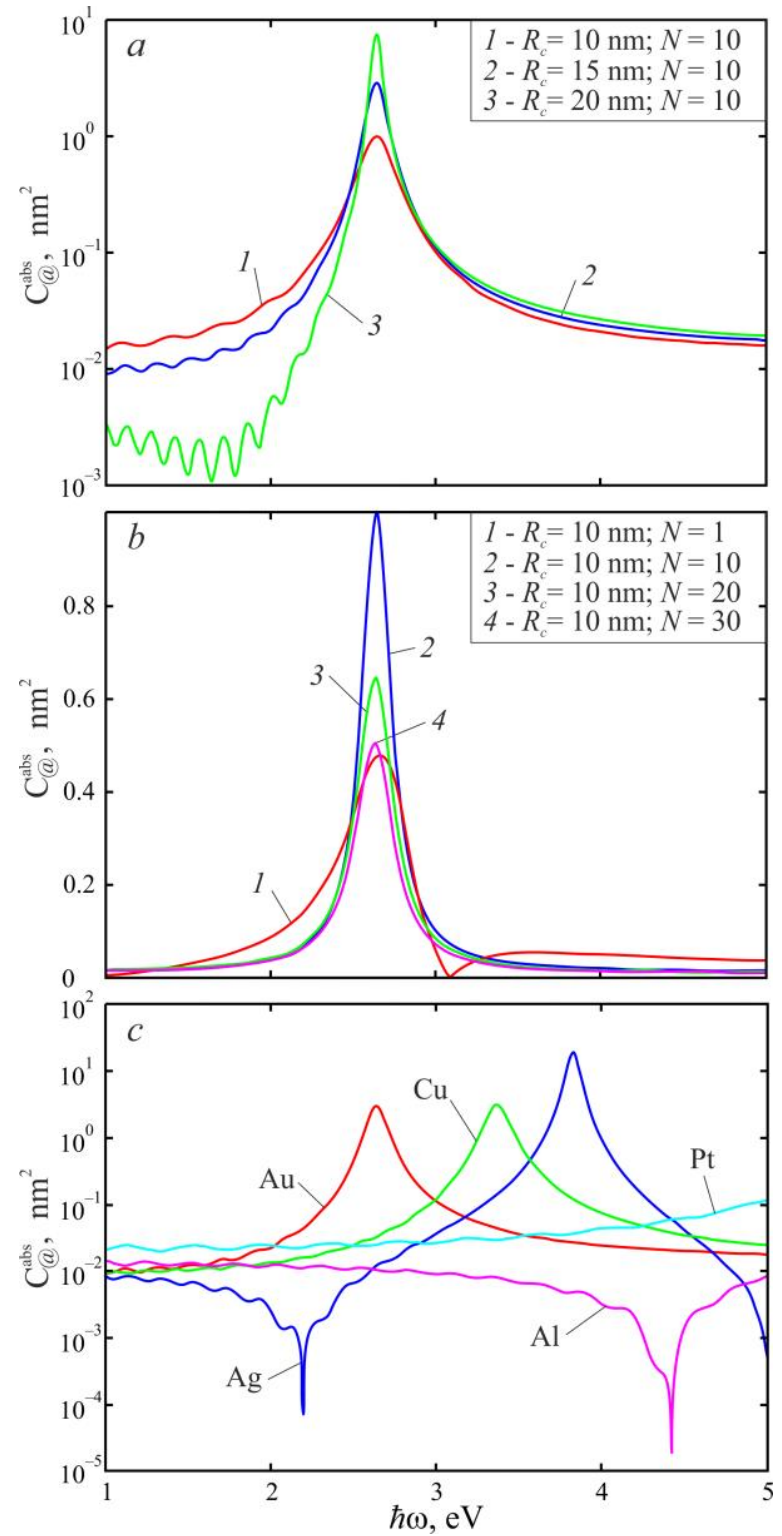

Fig. 4-Frequency dependences of the absorption crosssection of metal-graphene nanoparticles with different radius of the core (a), different thickness of graphene layers (b) and with a core of different metals (c)
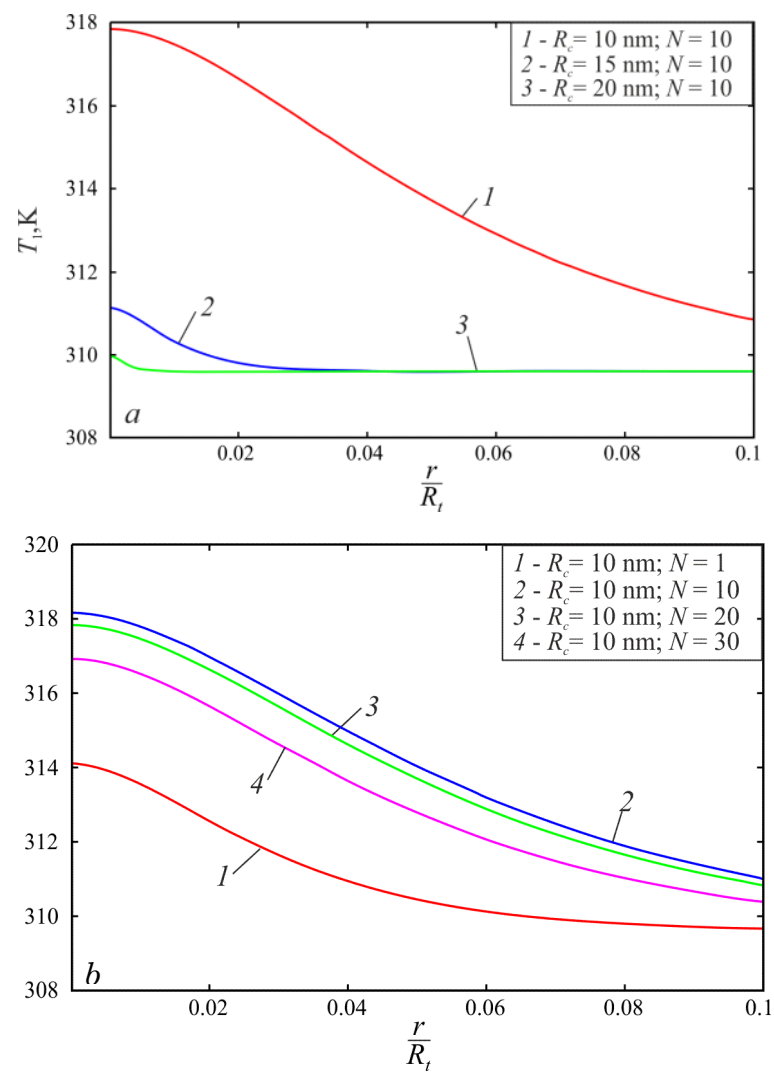

Fig. 5-Temperature distributions in the tumor for Au@G nanoparticles: $\mathrm{a}$ - different radius of the core; $\mathrm{b}$ - different thickness of graphene layers

Heating, which is sufficient for tumor tissue necrosis, is noticeable only in the case of a nanoparticle with $R_{c}=10 \mathrm{~nm}$ and the number of graphene layers $N=10$ and a domain $r^{*} \cong 0.1 R_{t}$, which indicates the need either to move the nanoparticle or to use a conglomerate of nanoparticles for therapy.

\section{CONCLUSIONS}

A model for the determination of heating of body tissue as a result of the excitation of plasmon resonances in metal-graphene nanoparticles injected into malignant tumor has been proposed.

It has been established that the maximum value of the imaginary part of the polarizability and, accordingly, the absorption cross-section increase both with an increase in the radius of the metal core and with an increase in the graphene shell thickness. This can be explained by the amplification of the response to external electromagnetic effects with an increase in the metal content in the nanoparticle and by the manifestation of the metallic properties of graphene layers.

The spectral shift of the maxima of the crosssections is possible with the variation of the material of the nanoparticle core, which is associated with a significant difference between the frequencies of bulk plasmons and the contribution of the crystal lattice to the dielectric function of considered metals.

It has been proved that the thermal conductivity in the given problem is considered to be steady.

The numerical estimates indicate that heating of 
healthy tissues is insignificant, hence, this method of cancer therapy is harmless to healthy tissues and the body as a whole.

The performed calculations show that heating, which is sufficient for tumor necrosis, takes place in a

\section{REFERENCES}

1. L. Dykman, N. Khlebtsov, Gold Nanoparticles in Biomedical Applications (CRC Press: 2019).

2. Y. Liu, P. Bhattarai, Z. Dai, X. Chen, Chem. Soc. Rev. 48, 2053 (2019).

3. A. Gao, W. Xu, Y. Ponce de León, Y. Bai, M. Gong, K. Xie, B.H. Park, Y. Yin, Adv. Mater. 29, 1701070 (2017).

4. L. Guerrini, N. Pazos-Perez, E. Garcia-Rico, R. AlvarezPuebla, Cancer Nanotechnol. 8, 5 (2017).

5. M. Kim, J.-H. Lee, J.-M. Nam, Adv. Sci. 6, 1900471 (2019).

6. J.-E. Park, M. Kim, J.-H. Hwang, J.-M. Nam, Infrared Window Small Methods, 1, 1600032 (2017).

7. X. Huang, I.H. El-Sayed, W. Qian, M.A. El-Sayed, J. Am. Chem. Soc. 128, 2115 (2006).

8. X. Huang, P.K. Jain, I.H. El-Sayed, M.A. El-Sayed, Lasers Med. Sci. 23, 217 (2008).

9. Z. Behrouzkia, Z. Joveini, B. Keshavarzi, N. Eyvazzadeh, R.Z. Aghdam, Oman Med. J. 31, 89 (2016).

10. R.W. Habash, R. Bansal, D. Krewskiand, H.T. Alhafid, Crit. Rev. Biomed. Eng. 34, 491 (2006).

11. J.R. Oleson, T.V. Samulski, K.A. Leopold, S.T. Clegg, M.W. Dewhirst, R.K. Dodgeand, S.L. George, Int. J. Radiat. Oncol. Biol. Phys. 25, 289 (1993).

12. D. Jaque, L.M. Maestro, B. DelRosal, P. Haro-Gonzalez, A. Benayas, J. Plaza, E.M. Rodriguezand, J.G. Sole, Nanoscale. 16, 9494 (2014).

13. M.A. Albota, C. Xuand, W.W. Webb, Appl. Opt. 37, 7352 (1998).

14. J.G. Teeguarden, P.M. Hinderliter, G. Orr, B.D. Thralland, J.G. Pounds, Toxicol. Sci. 95, 300 (2006). relatively small neighborhood of the nanoparticle (with a radius of the order of tenths of the tumor radius), and, hence, it seems appropriate to use a conglomerate of nanoparticles for the therapy.
15. W.Y. William, E. Chang, R. Drezekand, V.L. Colvin, Biochem. Biophys. Res. Commun. 348, 781 (2006).

16. E. Porcel, S. Liehn, H. Remita, N. Usami, K. Kobayashi, Y. Furusawa, C. LeSech, S. Lacombe, Nanotechnol. 21, 085103 (2010).

17. S. Wang, P. Huang, L. Nie, R. Xing, D. Liu, Z. Wang, J. Lin, S. Chen, G. Niu, G. Lu, X. Chen, Adv. Mater. 25, 3055 (2013).

18. G. Terentyuk, E. Panfilova, V. Khanadeev, D. Chumakov, E. Genina, A. Bashkatov, V. Tuchin, A. Bucharskaya, G. Maslyakova, N. Khlebtsov, B. Khlebtsov, Nano Res. 7, 325 (2014)

19. S.S. Chou, B. Kaehr, J. Kim, B.M. Foley, M. De, P.E. Hopkins, J. Huang, C.J. Brinker, V.P. Dravid, Angew. Chem. Inte. Ed. 52, 4160 (2013).

20. X. Song, H. Gong, S. Yin, L. Cheng, C. Wang, Z. Li, Y. Li, X. Wang, G. Liu Z. Liu, Adv. Funct. Mater. 24, 1194 (2014).

21. X. Bian, Z.-L. Song, Y. Qian, W. Gao, Z.-Q. Cheng, L. Chen, H. Liang, D. Ding, X.-K. Nie, Z. Chen, W. Tan, Chemotherapy Sci. Rep. 4, 6093 (2014).

22. K. Yang, S. Zhang, G. Zhang, X. Sun, S.-T. Lee, Z. Liu, Nano Lett. 10, 3318 (2010).

23. Y. Wang, K. Wang, J. Zhao, X. Liu, J. Bu, X. Yan, R. Huang, J. Am. Chem. Soc. 135, 4799 (2013).

24. A.V. Korotun, A.O. Koval, V.V. Pogosov, Ukr. J. Phys. 66, $518(2021)$

25. N.I. Grigorchuk, P.M. Tomchuk, Phys. Rev. B 84, 085448 (2011).

26. N.I. Grigorchuk, J. Opt. Soc. Am. B 29, 3404 (2012).

27. M. Farokhnezhad, M. Esmaeilzadeh, J. Phys. Chem. C 123 , 28907 (2019)

\title{
Моделювання теплових явищ у біологічних тканинах, викликаних поверхневим плазмонним резонансом у метал-графенових наночастинках
}

\author{
Н.А. Смирнова ${ }^{1}$ Р.О. Малиш ${ }^{1}$, А.В. Коротун ${ }^{1}$, В.І. Рева ${ }^{1}$, І.М. Тітов ${ }^{2}$
}

${ }^{1}$ Національний університет «Запорізька політехніка», вул. Жуковського, 64, 6906з Запоріжж, Украӥна 2 UAD Systems, вул. Олександрівська, 84, 69002 Запоріжж, Україна

\begin{abstract}
Проаналізовано можливість використання розігріву біологічних тканин при збудженні поверхневих плазмонів у двошарових сферичних метал-графенових наночастинках для термодеструкції злоякісних новоутворень. Для визначення частотних залежностей діелектричної функції металевого ядра провідності графенової оболонки використано моделі Друде і Кубо, відповідно, а розподіли температури в тканинах пухлини та оточуючих її здорових тканинах визначаються розв’язками неоднорідних рівнянь теплопровідності. Для чисельних оцінок і розрахунків використано відомі з літератури значення теплофізичних параметрів тканин пухлини і здорових тканин людини. Досліджено еволюцію частотних залежностей поляризовності і перерізів поглинання вказаних наночастинок при зміні радіусу і матеріалу металевого ядра і товщини графенової оболонки. Показано, що зі збільшенням радіусу металевого ядра або товщини графенової оболонки відбувається зростання максимальних значень уявної частини поляризовності і перерізу поглинання, що пов’язано з підсиленням взаємодії з електромагнітною хвилею зі збільшенням об’емного вмісту металу у композитній наночастинці і високою концентрацією вільних електронів у графенових шарах. Продемонстровано можливість спектральних зсувів максимумів поляризовності і перерізу поглинання при зміні матеріалу ядра двошарової наночастинки внаслідок суттевої різниці у значеннях частот об’емних плазмонів і внеску іонного остову в діелектричну функцію. Встановлено, що теплопровідність в задачі про нагрівання біологічних тканин при збудженні поверхневого плазмонного резонансу у композитній наночастинці є квазістаціонарною. Доведено, що даний метод терапії раку е нешкідливим для здорових тканин, що оточують пухлину, внаслідок їх вкрай незначного нагрівання. Результати чисельного моделювання свідчать про необхідність застосування конгломерату метал-графенових наночастинок з метою підвищення ефективності терапії.
\end{abstract}

Ключові слова: Метал-графенова наночастинка, Поляризовність, Переріз поглинання, Плазмонний резонанс, Термодеструкція. 